\title{
Monitoring of the impact factors of employee compensation incentive of big data enterprises based on structural equations
}

\author{
Shen Qing Qing ${ }^{1}$ Feng Jiang Hua ${ }^{1}$ \\ ${ }^{1}$ Shanghai Technical Institute of Electronics Information Shanghai, China
}

\begin{abstract}
Through the perspective of employees of big data enterprises in Jiangsu, Zhejiang and Shanghai, data were obtained in the form of questionnaire research, the significance of the influence factors of compensation incentive is evaluated, and the use of the empirical method of structural equations is obtained, and all indicators play a positive incentive role. Among them, the four indicators of salary performance, prospect promotion, equity incentives and welfare benefits are highly motivating. At the same time, four countermeasures are put forward:1. While implementing long-term and short-term salary incentives, pay attention to the principle of ability and performance first; 2 . Provide basic benefits and improve the retirement mechanism for employees; 3. Strengthen humanistic care and create simple interpersonal relationships and good communication atmosphere; 4. Improve the post promotion mechanism, clear employee career channel.
\end{abstract}

\section{Introduction}

At present, "big data" has become one of the most important areas of concern to all walks of life in the world. In 2014, the relevant departments of our country introduced a series of policy measures around big data, which made the development and application of big data technology become the main direction of industry development. A large number of companies related to big data applications and data commercialization have emerged as the times require. These big data companies that tap the business value behind data and create revenue for them have entered a fierce competition [1].Talent has become an important condition for such enterprises to be able to stabilize in a complex and changing competitive environment. Salary, as one of the tools to motivate talents, how to exert its function of attracting, retaining and encouraging employees to work actively has become a problem that big data enterprises must focus on solving. Therefore, this article investigates the salary situation of employees in big data companies, allows employees to evaluate the current salary situation, and finally puts forward suggestions based on empirical analysis results, which has certain practical significance.

\section{Literature Review}

Definition of big data enterprises: this paper adopts the view of Cha HongWang that enterprises with data collection, storage, mining and application as the main mode of operation are big data enterprises[2]. For compensation areas, Martocchi believes that compensation consists of both internal and external rewards[3].Stephen Robbins believes challenging tasks can motivate employees more quickly than intuitive monetary pay, combining training and promotion to motivate them to make progress[4]. Ren Li (2013) [5] and Wang Yu (2017) [6] and other scholars around the Internet enterprise employees pay research, put forward the lack of competitiveness of wages, performance appraisal lack of accuracy and the welfare system is not perfect, and build a compensation incentive system. Therefore, All employees in the information, technology, and service industries that focus on data mining and business value development are the objects of this survey; at the same time, it is defined as total compensation in the broad sense, including dual compensation in monetary and non-monetary terms. The indicators involved include and are not limited to monetary compensation such as wages, bonuses and benefits, as well as non-monetary compensation such as social status, future development, and job challenges, and use this definition to design questionnaires, complete surveys and empirical analysis.

\section{Research and Design}

Part 1: questionnaire design. Combining the broad definition of salary, this survey involves two modules, first of all, the basic information, which includes five indicators, such as location, education level, working years and job position, followed by the main information of the questionnaire, which includes six categories and 21 indicators, and the Likert scale is used to design the options, that is, "very important, important, normal, unimportant, completely unimportant" to set, and the 
five options are assigned one by one to "5, 4, 3, 2, 1" to assign points and calculate. The letters in the table represent the corresponding symbol of the variable, as detailed in Table 1:

\section{TABLE I. SUMMARY OF INFLUENCING FACTORS OF} SALARY INCENTIVES

\begin{tabular}{|c|c|c|}
\hline $\begin{array}{l}\text { One- } \\
\text { level }\end{array}$ & Two-level & Three-level \\
\hline \multirow{6}{*}{$\begin{array}{l}\text { Salary } \\
\text { incenti } \\
\text { ves-Z }\end{array}$} & $\begin{array}{l}\text { Working } \\
\text { Atmosphe } \\
\text { re-a }\end{array}$ & $\begin{array}{l}\text { A1 rich league building activities, A2 } \\
\text { good teamwork, A3 good leadership }\end{array}$ \\
\hline & $\begin{array}{l}\text { Prospect } \\
\text { promotion } \\
\text {-b }\end{array}$ & $\begin{array}{l}\text { B1 prospect of work development, B2 } \\
\text { space for promotion }\end{array}$ \\
\hline & $\begin{array}{l}\text { Salary } \\
\text { performan } \\
\text { ce-c }\end{array}$ & $\begin{array}{l}\text { C1 performance determines salary, C2 } \\
\text { year-end bonus is paid on time, C3 } \\
\text { annual opportunities for salary } \\
\text { increases, C4 guaranteed salary }\end{array}$ \\
\hline & \begin{tabular}{|l|} 
Equity \\
incentive- \\
d
\end{tabular} & $\begin{array}{l}\text { D1 performance shareholdings, } \\
\text { D2shareholding by seniority, D3 } \\
\text { shareholding based on job level }\end{array}$ \\
\hline & $\begin{array}{l}\text { Working } \\
\text { mode -e }\end{array}$ & $\begin{array}{l}\text { E1 flexible work, E2 private circle of } \\
\text { friends should provide certain } \\
\text { compensation for the release of work } \\
\text { content, E3 management humanity, E4 } \\
\text { provides extra humanistic care such as } \\
\text { meal stickers and car stickers when } \\
\text { working overtime, E5high salary } \\
\text { incentives and the implementation of } \\
\text { the end elimination system }\end{array}$ \\
\hline & Welfare-f & $\begin{array}{l}\text { F1 five insurance and one housing fund, } \\
\text { F2 supplementary commercial } \\
\text { insurance, F3 comprehensive welfare } \\
\text { allowance, F4 retirement pension } \\
\text { protection }\end{array}$ \\
\hline
\end{tabular}

Part 2: research objects and descriptions. After the preliminary survey and revision of the questionnaire, the survey of employees in big data companies in Jiangsu, Zhejiang and Shanghai was completed by sending questionnaire links online. The main methods include headhunting channels, joining the QQ communication group of information, technology and service related companies, sending links through corporate recruitment mailboxes, using channels of school-enterprise cooperation, transferring links to students working in the above companies, and joining big data Industry discussion groups, and field visits to three Internet companies, etc, eventually collected 213 basic data.

\section{Empirical analysis}

Structural Equation Model (SEM) provides a tool that can be analyzed and detected under the premise that the latent variable cannot be directly observed in actual work. Structural equations consist of structures and measurement models. The role of the structural model: reveal the relationship between the latent variables; the role of the measurement equation model: reveal the relationship between the latent variable and the observed variable. The equations are as follows:

$$
\begin{aligned}
& \eta=B \eta+\Gamma \xi+\zeta \\
& y=\Lambda_{y} \eta+\varepsilon \\
& x=\Lambda_{x} \xi+\delta
\end{aligned}
$$

Note: equations (1) represent structural equations, and (2) and (3) are equations of measurement equations. The meanings of the letters in each equation are summarized as follows: $\eta$ (endogenous latent variable), $\xi$ (exogenous latent variable), $\zeta$ (residual error, error term); y (endogenous observed variable), $\Lambda$ y(endogenous observed variable and Relationship between endogenous latent variables), $\varepsilon$ (residual error, error term); $\mathrm{x}$ (exogenous observation variable), $\Lambda \mathrm{x}$ (relationship between exogenous observation variable and exogenous latent variable), $\delta$ (residual error, error item).

Based on 21 observable variables, this article analyzes the relationship between salary incentives and 6 latent variables such as working atmosphere, prospect promotion, salary performance, equity incentive, operating mode and welfare.

\subsection{Reliability and validity detection}

To ensure the credibility of subsequent analysis, Cronbach's alpha was used to complete the test for 213 valid questionnaire data; KMO and Bartlett's Test were used for questionnaire validity. The results are as follows: $\alpha=0.849 ; \mathrm{KMO}=0.856$, sig $=0.000$, therefore, the results also show that the variable factor is adapted for factor analysis.

\subsection{Descriptive statistics}

First, location distribution: Zhejiang(109,51.17\%), Shanghai(65,30.52\%), and Jiangsu(39,18.31\%).Second, gender: male(131,61.5\%), female(82,38.5\%).Third, education level: junior college or below $(30,14.1 \%)$, undergraduate $(97,45.5 \%)$, master( $81,38 \%)$, doctorate $(5,2.3 \%)$. Fourth, working years: 1 year and below(41,19.2\%), 1 <working years $\leq 2(104,48.8 \%), 2$ $<$ working years $\leq 3(27,12.7 \%)$, greater than $3(41,19.2 \%)$.Fifth, jobs: algorithm engineer $(54,25.35 \%)$, ETL development(31,14.55\%), Hadoop development(37,17.37\%), project testing $(21,9.86 \%)$, data product manager(9,4.23\%), OLAP development $(26,12.21 \%)$, operation and maintenance architect(12,5.63\%), java development(15,7.04\%), and other( $8,3.76 \%)$. To sum up, the audience of this survey focused on 5 characteristics: Zhejiang $(51.17 \%)$, male $(61.5 \%)$, undergraduate $(45.5 \%), 1<$ working years $\leq 2$ $(48.8 \%)$ and algorithm engineers $(25.35 \%)$.

\subsection{Model construction and analysis}

On the AMOS24.0 platform, a weighted least squares method (WLS) is used to build a structural model and complete a confirmatory factor analysis of the six variables and 21 indicators that are the influencing factors of employee compensation incentives in big data 
companies. In AMOS24.0, the residual term and factor load are all set with a default weight of 1 . The final calculation is completed and the standardized result is obtained. The specific variable model is shown in Figure 1:
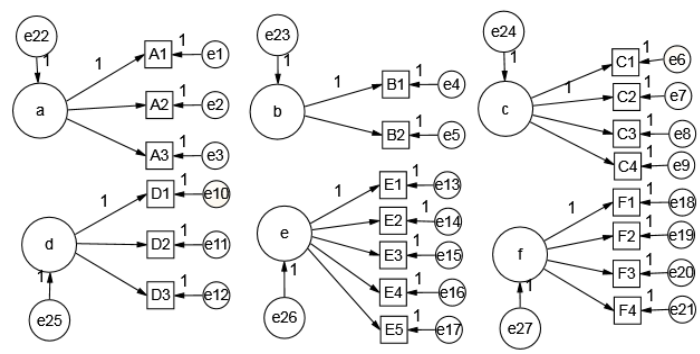

Figure 1 Structural model of influencing factors of compensation incentives

Calculated by AMOS24.0, the fitted results of the model are $\chi^{2}=316.54, \mathrm{df}=183.00, \chi^{2} / \mathrm{df}=1.73 \quad(<$ $3), \mathrm{TLI}=1.00(>0.9), \mathrm{CFI}=0.98 \quad(>0.9)$, RMSEA $=0.06(<0.08)$, that is, the fitting degree passes the adaptation standard. From this, a second-order factor model is constructed and the model parameter estimation is completed. The results are shown in Figure2.

Combining the content description of the previous structural equation and the calculation results of the model, the following equation is obtained:

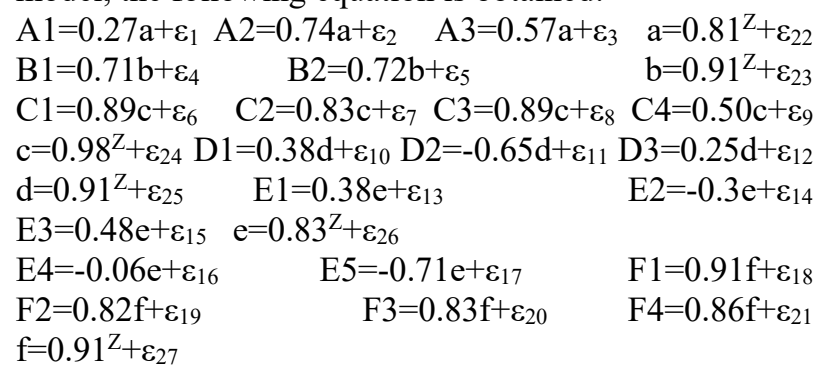
$\mathrm{B} 1=0.71 \mathrm{~b}+\varepsilon_{4} \quad \mathrm{~B} 2=0.72 \mathrm{~b}+\varepsilon_{5} \quad \mathrm{~b}=0.91^{\mathrm{Z}}+\varepsilon_{23}$ $\mathrm{C} 1=0.89 \mathrm{c}+\varepsilon_{6} \quad \mathrm{C} 2=0.83 \mathrm{c}+\varepsilon_{7} \mathrm{C} 3=0.89 \mathrm{c}+\varepsilon_{8} \mathrm{C} 4=0.50 \mathrm{c}+\varepsilon_{9}$ $\mathrm{c}=0.98^{\mathrm{Z}}+\varepsilon_{24} \mathrm{D} 1=0.38 \mathrm{~d}+\varepsilon_{10} \mathrm{D} 2=-0.65 \mathrm{~d}+\varepsilon_{11} \mathrm{D} 3=0.25 \mathrm{~d}+\varepsilon_{12}$ $\mathrm{d}=0.91^{\mathrm{Z}}+\varepsilon_{25} \quad \mathrm{E} 1=0.38 \mathrm{e}+\varepsilon_{13} \quad \mathrm{E} 2=-0.3 \mathrm{e}+\varepsilon_{14}$ $\mathrm{E} 3=0.48 \mathrm{e}+\varepsilon_{15} \quad \mathrm{e}=0.83^{\mathrm{Z}}+\varepsilon_{26}$ $\mathrm{f}=0.91^{\mathrm{Z}}+\varepsilon_{27}$

\subsection{Result analysis}

First, the working atmosphere: all three indicators play a positive incentive role. Among them, good teamwork and good leadership have a greater impact, with factor loadings of 0.74 and 0.57 , respectively. Second, prospect promotion: prospect of work development (0.71), and space for promotion (0.72) all play a positive incentive role. Third, the salary performance: the four indicators all play a positive incentive role. Among them, performance determines salary (0.89) and annual salary increase opportunities (0.89) have a greater impact. Fourth, equity incentives: the incentive effect of performance shareholdings is relatively large (0.38). Fifth, the working mode, flexible work (0.38) and management humanity $(0.48)$ indicators play a positive incentive role. Sixth, welfare benefits: the four indicators all play a positive incentive role, of which the two indicators of the five insurance and one housing fund (0.91) and retirement pension protection (0.86) have a greater impact. On the whole, six indicators, such as work atmosphere, prospect promotion, salary performance, equity incentives, work mode, and welfare, have a positive effect on salary incentives, and their factor loads are $0.81,0.91,0.98,0.91,0.83$, and 0.91 . Among them, the impact of salary performance, prospect promotion, equity incentives and welfare is higher. 


\section{Conclusion and suggestion}

\subsection{Conclusion}

Based on the evaluation of 213 respondents on various indicators under the definition of generalized compensation, it was concluded that the key indicators that play a major incentive role are concentrated in 4 items: salary performance, prospect promotion, equity incentives and welfare. Therefore, the long-term and short-term incentives for compensation, the welfare that match the current job, and the future development and promotion space of the job have become very important factors for employees.

Specifically, the employees interviewed believe that: first, the team can cooperate well, and at the same time, corporate leaders can get along easily, which will play a positive role in the work; second, facing the fast-paced and high pressure of big data companies, flexible work and more humane management will promote work; third, the five insurance and one housing fund and retirement pension protection are the most important factors for employees in welfare; fourth, for salary incentives, performance determines salary and annual opportunities for salary increases have a better effect on short-term incentives; performance shareholdings have a long-term incentive for employees.

\subsection{Suggestions}

1) While implementing long-term and short-term salary incentives, pay attention to the principle of ability and performance first. At present, the age of employees in big data companies is generally younger. For young employees who come to work hard in Jiangsu, Zhejiang, and Shanghai, the first concern is the monthly income after tax. The level of this income will directly determine the quality of life of this group or even whether it can continue stay in this city. Therefore, short-term compensation is the primary factor that can quickly inspire young employees to work hard and ensure that they can work with peace of mind. The important factor that affects the level of short-term pay is performance. To determine the level of short-term pay of employees based on performance is the pay distribution plan that respondents expect.

At the same time, through the opportunity to raise salary every year, while letting employees feel comfortable doing their job, they can further stimulate the employees' continuous enthusiasm to work seriously. In addition, combining the principle of competence first, giving high-performing employees the opportunity to obtain company stocks, and then realize long-term incentives, which will prompt employees to change from a passive work perspective to the idea of growing together with the company. This provides conditions for retaining talents and achieving the company's stable development goals.
2) Provide basic benefits and improve the retirement mechanism for employees. 213 subjects also paid special attention to future retirement. The current fast-paced and high pressure of big data companies and even some companies implementing the last elimination system are factors that have become the main cause of uneasiness for young employees. The large-scale layoffs of some Internet or high-tech companies have made the "middleaged crisis" a fact that young employees must face, and then a phenomenon has emerged: young employees work hard to accumulate a certain amount of wealth before their middle age, At the same time, it will pay attention to the recruitment information of other companies to achieve the transition from high-paying companies to such units with good treatment, good benefits, and peace of retirement. This will be a loss of talents for the original unit, and it will not be conducive to the construction of the enterprise talent team. Therefore, in view of long-term development, big data companies, especially Internet companies, must improve their employees' retirement and retirement mechanisms in accordance with their own development plans. On the one hand, it is necessary to provide competitive salaries for young employees who have just entered the company, and on the other hand, to provide a secure future for middle-aged employees and senior employees who have become the backbone of the company, so as to promote stable, orderly and sustainable development of the company. .

3) Strengthen humanistic care and create simple interpersonal relationships and good communication atmosphere. 213 subjects believed that flexible work and humane management helped to improve work motivation. Enterprises can set up flexible commuting hours, attendance systems, overtime allowances and other measures on the premise that work tasks or project processes are not affected, so that employees have some time to handle family affairs during work. Aiming at younger enterprise employees, keep things simple, create a simple interpersonal relationship and a good communication atmosphere, and promote the smooth development of work.

4) Improve the post promotion mechanism, clear employee career channel. 213 subjects considered that the prospect of job development and the space for job promotion were also one of the focuses of attention. While providing competitive compensation, enterprises should improve the company's position promotion mechanism and development channels, and form a complete promotion space from new employees to expert employees or expert management talents. Combine this with a comprehensive job description, comprehensive employee quality assessment, and manpower selection system to ensure that this measure is implemented. 


\section{References}

1. McAffe A, Brynolfsson E. Strategy \& competition big data: the management revolution[J]. Harvard Business Review,2012,90(10):60-66.

2. Cha HW,Cai GL. Evaluation of Innovation Efficiency of Big Data Enterprises in ChinaBased on DEA Method[J].Journal of Beijing University of Posts and Telecommunications: Social Sciences Edition, 2017, 19(1):71-78.

3. Zhong XF, Chen Z. Structural Equation Analysis of Employees' Salary in Private Enterprises[J].
Research on Financial and Economic Issues.2010(09):125-12

4. Stephen P. Robbins: Management (Fourth Edition), Beijing: Renmin University of China Press, 1997

5. Ren 1. Analysis of comprehensive salary incentives for knowledge workers in the Internet industry[D]. China University of Political Science and Law, 201

6. Wang Y. Research on Salary Management of Management Staff in Internet Companies[D]. Capital University of Economics and Business,2017. 